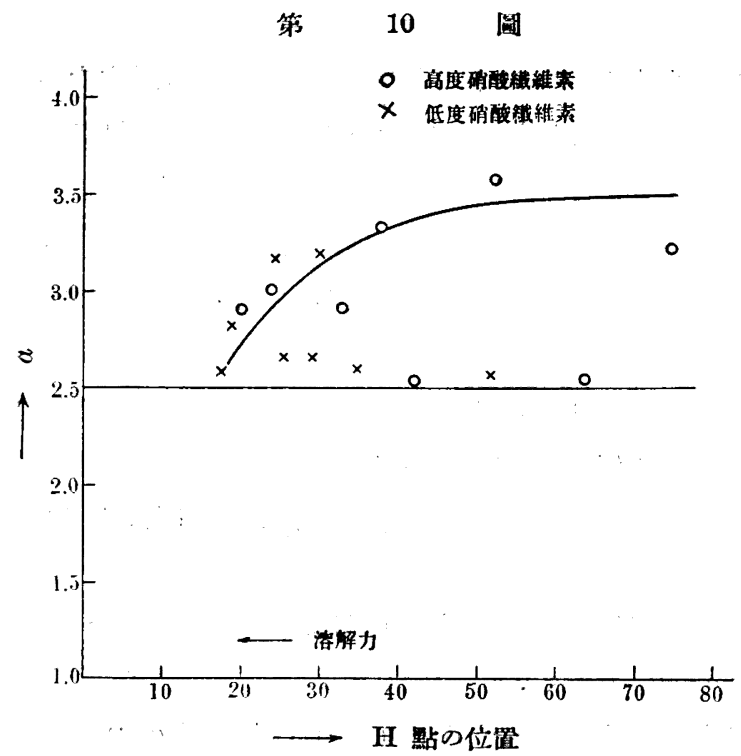

それに化てより小さくなると云ふ事の可能性も 考へられる。同樣な事苗は既に酷酸繊維素のク ロロフォルムーベンザール2成分采に對する場合 に於ても認められた所である(李・櫻田, 本誌, 昭和 $8 、 1933 ， 36,329$ )。

更に興味あるのは形狀電荷係數 $a$ と溶解力と の關俰である。これらの關係を聞示したすのは 第 10 圆であるがこ〉に $a$ の值は無電荷球形の 粒子のもつ值 2.5 から左程遠さかづてるないと 云ふ事は特に翼樣の感を抱かせる。そして如何 なる溶劑に於ても $a$ は 2.5 よりるり小さく ない。畄を統計的に見て大體さつの傾向が存在 する事か明白である。その 1 つは $\alpha$ の大さは 溶解力の增加と共に減少するものであり，他の

1 つは溶解力には無留係な然も 2.5 の值に近いものである。此賽驗に於ては如何なる場合にもかくの如き硝酸 瀻維素の粘子の形は球形から左程溒ざかつてるないと考へられる。

IV. 總 括

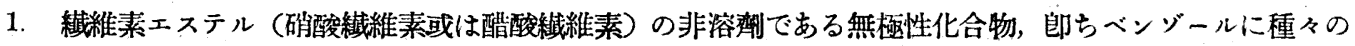
量の溶淛を加一混合液をつくりそれを用ひて瀻維素エステルの溶解度曲線を求めそれに依て各種溶劑の溶解力 を直接比較する方法を證明した。

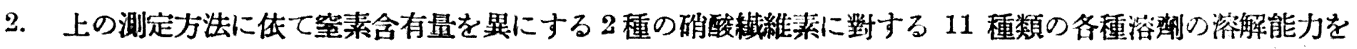
此較した。

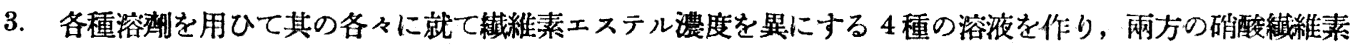
に就てその溶剂に對する比粘度を測定した。粘度測定から得た數值を用ひて我々の方法に從つて比容積 $\varphi$ 及 形狀電荷係數 $a$ の值を算出した。

4. 溶解力の埥加と共に溶液の比粘度及比容積は減少する。

5. どの溶韧に於ても形狀電荷保數 $a$ の值は無電荷球形の粒子のもつ值 2.5 に近い。

(京都帝國大學工學部工業化學敉室・理化學研究所喜多研究室)（昭和 9 年 7 月 21 日受理）

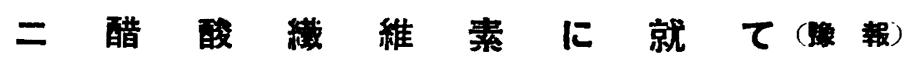

櫻田一郎・北畕 東三

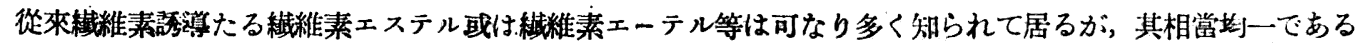
と考へられるるのは殆ど全部緎維素の有する 3 個の $\mathrm{OH}$ が全部一樣に反應した三ェステル化物或は三ェてテ ル化物であつて，一或は二ェステル化物邓はエーテル化物等は㤧ど全く知られて居ない。 
B. Helferich 及 H. Koester は繊維素の Triphenylmethyl (略して Trityl 或はトリチル) 誘導體として 㫌䊒素の $\mathrm{C}_{6} \mathrm{H}_{10} \mathrm{O}_{5} 1$ 個に 1 個のトリチル基の結合したものを得,これより高級なエーテルは得られなかつ た (Ber., 1924, 57, 587)。B. Helferich 自身及び他の㸴究者により簡單なアルコール類及び糖類に關して多數 の研究が行はれ第 1 級の - OH 基のみかトリチル化される事がよく知られて居る。この類似性から上に得られ たトリチル化繊維素は繊維素の第 1 級の $\mathrm{OH}$ 郎ち 6 の位置の $\mathrm{OH}$ のみが選擇的に反應した 6 ・モノ・トリチ ル化繊維素であると考へられる。此樣な化合物が一定の空間格子を有して居るか否かに關してはまだ研究の發 表されたものはない。

興味の有るのは最近の Hess, Trogus 等のアルカリ瀻維素のメチル化に關する研究で, 彼等は此際に明膫な 一定の空間格子を有する Halbmethylat 郎ち $\mathrm{C}_{6} \mathrm{H}_{10} \mathrm{O}_{5} 2$ 個に關し 1 個のメチルの入つた化合物を得た。

其他繊維素の 3 個の $\mathrm{OH}$ が選擇性を示すと考へられる例も相當多いが(中島・櫻田, 本誌, 昭和 4, 1929, 32,24）いづれる確實な證據はない。

工業上よく知られて居るコロヂウムは登素含有率は大體 $11.2 〜 12.4 \%$ であり $\mathrm{C}_{6} \mathrm{H}_{10} \mathrm{O}_{5} 1$ 個に對し2〜2.5 個 の硝酸基が結合した割合である。水を含有した湿酸から製られるコロヂウムは從來よく知られて居る如くエス テル化と蛤化が一定の硝化度で本衡に達したものであるから（例へば Berl u. Barkenfeld, Z. angew. Ch., 1928, 41, 130; F. D. Miles \& J. Craik, J. Phys. Chem., 1930, 34, 2604)。簡單な三硝酸械維素と末反㤫の緎. 維素の混合物であるとは考へられない。最近 Hess, Trogus はュロデウムに相當する硝化物の從來知られて居 る $X$ 線圖に關して報告し其圖をコロヂウムの $X$ 線回と命名して居るが(Elektrochemie, 1934, 40, 193)其圖は 著者自身も云ふ如く非常に三硝酸緎維素のそれに類似して居り，化學的組成は同一であるが其立體構造の異る 基本體が集合して例へば混晶の如きものをつくり大體三硝酸瀻維素に近い空間格子を有するるのと思はれる。

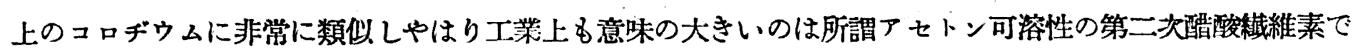
ある。其醋酸含有率は 50〜 $57 \%$ であり $\mathrm{C}_{6} \mathrm{H}_{10} \mathrm{O}_{5}$ に對し醋酸基が 2 2.5 個結合した割合である。此物質は コロデウムの如く第一次的には得られず三醋酸韯維素を加水分解して第二次的に得られる。普通此襝化は水の 存在で醋酸溶夜で行はれるがコロヂウムの時と異り畧化反應は本衡に達せず, 適當の時期に中斷せしめられる のである。此第二次のアセトン可溶性醋酸瀻維素は我々の研究に体れば（櫻田・古川, 本誌, 昭和 8, 1933, 36,

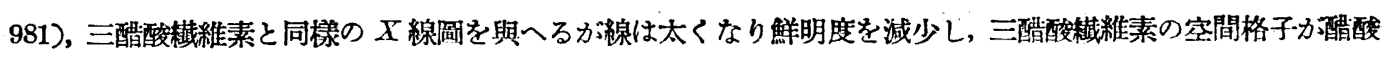
基の脫出により不規則になつた事は疑ひのないところである。此 $X$ 線的研究結果からもまた我々の.1人が以

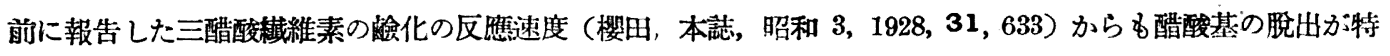
定の OH の位置に於て選擇的に起つたとは考へにくい。此見解に對する偷一の新しい支持は本報告の後牛に 於て述べる。

斯の如く一定の $\mathrm{OH}$ が選擇的に反隹したと考へられる低級エステルは從來知られて居ないから,かつる瀻 維素誘導體の研究の第 1 段として, 先づ工業的に見てもアセトン可溶性醋酸繊維素と密接な關係ある二醋酸瀻. 維の合成を下記の樣な見解の下に行ふ事にした。

1. 䋐維素のトリチル化＼cjkstart瀻維素をトリチル化すれば 6 の OH のみか汳赝して 6・モノ・トリチル緎維素 が出來る䇢であるから, Helferich 等の研究を反覆し，纷 $X$ 線的に生成物を吟味してこれを確める事。

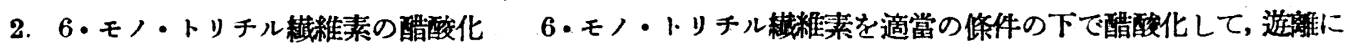
残留する 2 及 3 の位置の $\mathrm{OH}$ 基を醋酸化して, 2,3 ヂ・アセチル・6・モノ・トリチル結維素 (2,3-Diacetyl-6- 
monotrityl-cellulose) をつくる事。

3. 2,3-Diacetyl-6-monotrityl-cellulose よりトリチル基の除去 上記の醋酸化物よりエステルの踰化を 避けてトリチル基を除去し 2,3-Diacetyl-cellulose を得る事。

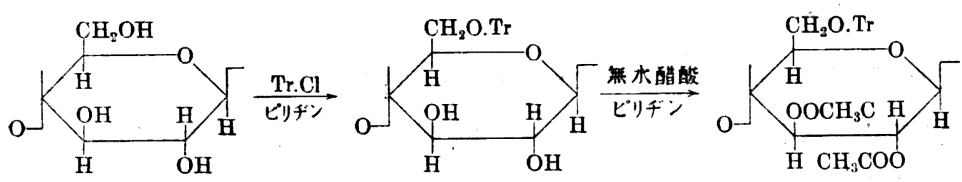
模维絭

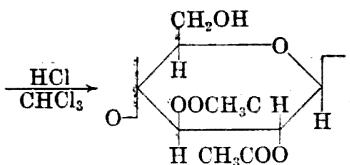

2,3-Diacetyl-cellulose
6-Monot rityl-cellulose
2,3-Diacetyl-6-Monotritylcellulose
斯の如くして2及 3 の $\mathrm{OH}$ に醋酸基が 入り, 6 の OH の遊 離の醌酸纎維素が得 られる筈である。

上記の計畫の下に實驗を行ひ，ほが目的通りの結果が得られたから尚幾 分不完全な個所もあるが㜈報として 報告する事にする。份トリチル基が 6 の $\mathrm{OH}$ のみに結合する事に着目し，市販のアセトン可溶性酷酸械維素（七 リ,ト)をトリチル化し，遊離の $\mathrm{OH}$ 中幾 \%が 6 の位置の第一級のアル コールに相當するかを知る事が出來た故に其結果も侀せて䍩告する。

\section{1. 繊維素のトリチルエーテル}

纎維菜のトリチル・エーテルに關しては上記の B Helferich 及 H. Koester の政究有るのみである。我令 は先つ纎維素のトリチル化物を得る目的で上記の研究者とほ心゙同樣の實驗を行つた。

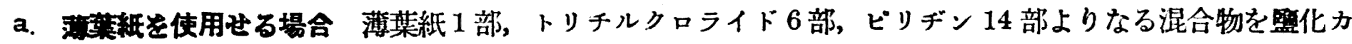
ルシウム管をつけた空氣冷却器付のフラスコに入れて湯浴中で加熱して緎維素のトリチル化を企てたが 150 時 間加熱してもピリヂンに不溶であつた。精製後收得量を見るのに $1.2 \mathrm{~g}$ の薄葉紙より $1.5 \mathrm{~g}$ の生成物が得られ ただけで反應は困難であつた。

b. 鍊㮶のトリチル化 銅絹を薄葉紙の場合と同樣に加熱すると 20３0時間で縝維素のトリチルエーテルを 生じビリヂンに溶解し，黑褐色の溶液となる。此繊維素トリチル溶液を $80^{\circ} \mathrm{C}$ の水に入れて沈浑を作り濾過 し, 水及アルコールで洗淡し, 次にアルュール可溶性の不純物 (主にトリチルカルビノール)をツっクスレーを 使用し〉ルコールで抽出した。斯くして得られる瀻維素トリチルエーテルはモノ・エーテルとしての理論數の 約 $80 \%$ である。

c. 分标法 上述の如くにして得た繊維素トリチルエーテルを10倍量のピリヂンに溶解し,アルコールで再 沈洀した試料を分析した。試料をピストル中で $100^{\circ} \mathrm{C}$ で乾燥し，試料 $1 \mathrm{~g}$ に對してクロロフォルム(脫水，脫 アルコールしたもの) $30 \mathrm{cc}$ を加へて 1 畵夜放置して充分膨潤せしめ（Helferich 等に依ればトリチルエーテ ルはクロロフォルムに可溶性であると云ふ）次に乾燥睤酸ガスを飽和せしめたクロロフォルム 10cc を加へる。 緎維素トリチルエーテルは分解して再生䋐維素とトリチルクロライドになる。前者は不溶であるから泌漕し，

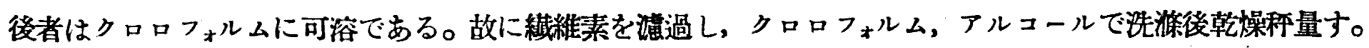
クロロフォルム洗澜液と濾液を一にし，空氣中の濕氣の入らないようにしてクロロフォルムを蒸溜し，最後に其 空で残留する少量のクロロフォルムを除き，後に牫つたトリチルクロライドを秤量する。

d. 分标結果 銅絹より製つたトリチル化䋐維素の分析結果は次の如くである。 


$\begin{array}{cc}\text { 試料番號 } & \text { トリチル化緎維素 } \mathrm{g} \\ 1 & 0.5750 \\ 2 & 0.8716 \\ 3 & 0.5984 \\ & 0.6650\end{array}$

理 論 数

再生䋘維素 $\mathrm{g}$
$0.2076(36.5 \%)$
$0.3338(38.2 \%)$
$02223(37.2 \%)$
$0.2517(37.8 \%)$

$40.1 \%$
トリチルクロライド $\mathrm{g}$

$0.5471(62.8 \%)$

$0.4053(67.9 \%)$

$0.4591(69.0 \%)$ $68.9 \%$

上記の分析結果を見れば殊に試料 3 は殆ど完全にモノ・エーテルの理論數に一致して居る事がわかる。再生 绕䊒素の收率が理論數に比して小であるのは，より高いエーテル化度を示す如くす思はれるが，實祭は主とし て再生の祭の機桟的損失であらら。

試料をピリヂンに浴解し，湯浴上でピリヂンを追出しフイルムを作り $X$ 線寫真を撮ると天然緎維素とす水

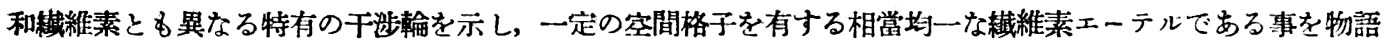
つて居る。他のアルコール或は糖のトリチル化物の研究結果と對比して繊維素の葡萄糖基の 6 の OH がエー テル化されたモノ・エーテルである事は確實である。

2. 纎維素トリチルェーテルの醋酸化

Helferich 等は繊維素モノ・トリチルエーテルをピリヂンに溶解し，無水醋酸を加へて湯浴中に加熱し，緎 維素トリチルェーテルを醋酸化した。醋酸含有率は加熱時間に依り異なるが彼等は遊離の 2 個の OH 1 個 が醋酸化された程度のものしか得なかつた。併乍ら瀻維素自身をほが同一方法て醋酸化すれば 3 個の OH が 全部醋酸化されるわけであり,トリチルエンテルの時む, 1 個の 6 の位置に入り达んだトリチル基が醋酸化を 妨げなければ殘餘の遊㒕の $\mathrm{OH}$ 全部か醋酸化される筈である。我々は下に示す如くトリチルエーテルを醋酸 化し，遊離の $\mathrm{OH}$ の全部醋酸化された 2,3-Diacetyl-6-trityl-cellulose とも名附け得べき誘導體を得た。

a. 醋酸化 緎維素トリチルエーテルをピリヂンに溶解し，それに當量の無水醋酸を加へて必要あれいば加第 して後放置した。無水醋酸を加へると 2,3 時間で羊掌狀となる。此鲳數日放置して後, 普通の酳酸緎維素の如 く精製して䋐維素トリチルエーテルの醋酸化物を得た。

試料 1. 䋐維素トリチルエーテル（試料 3 ）をピリヂンに浴解し，無水䤁酸を加へ 3 時間加熱し後 3 日間放 置した。

試料．2.上記の試料を更に 7 日間放置した。

試料 3. 全然加熱せずに 7 日間常溫でェステル化す。

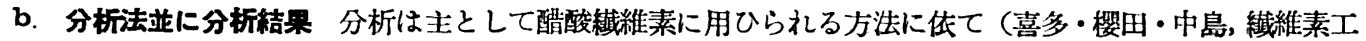

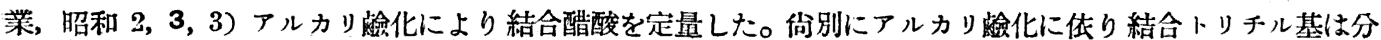
哏しない事を確めた。

酷酸化トリチル䋐維素の分析

\begin{tabular}{|c|c|c|c|}
\hline 試料番號 & 試料重最 $\mathrm{g}$ & 消費した $N / 10 \mathrm{KOH}$ cc & 科合醋酸 \\
\hline 1 & 0.9516 & $44.8 \quad(f=0.7869)$ & 22.2 \\
\hline 2 & 0.9258 & $44.28(\ldots)$ & 22.6 \\
\hline 3 & 0.8192 & $38.05(f=0.8010)$ & 22.4 \\
\hline \multicolumn{4}{|c|}{ Diacetyl-monotrityl-cellulose としての理諭數 } \\
\hline
\end{tabular}

醋酸含有率は幾分少いがほが理論數と一致する。

$$
\text { 3. 二醋 酸 䋞 維 素 }
$$

上記の 2,3-Diacetyl-6-monotrityl cellulose をクロロフォルムに浴解し（醋酸化すると可溶性になる）トリ 


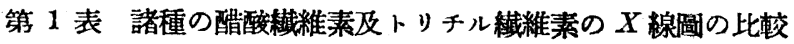

\begin{tabular}{|c|c|c|c|c|c|c|c|c|c|}
\hline 睛酸緎維䒺 & I & 醋酸䋐維素 & & $\begin{array}{l}\text { アセトンす̄ } \\
\text { 醋酸瀻 }\end{array}$ & 溶性 & $\begin{array}{l}\text { 2,3-Diac } \\
\text { cellulos }\end{array}$ & $e^{t^{\prime}-}$ & トリチル䋐 & 维妻 \\
\hline 干啮點强度 & $d(\AA)$ & 干选點强度 & $d(\AA)$ & 干啮點强度 & $d(\AA \AA)$ & 千橴點强度 & $d(\AA)$ & 干造點强度 & $d(\AA \AA \AA)$ \\
\hline 大 强 & .11 .4 & 大 强 & 10.43 & 大 强 & 11.4 & 大 强 & 9.7 & 强 & 14 \\
\hline 中 强 & 5.23 & 大 强 & 8.62 & 弱 & 5.40 & 强 & 4.65 & 弱 & 7.45 \\
\hline 弱 & 4.29 & 强 & 6.67 & 弱 & 4.42 & 弱 & 3.40 & 强 & 4.57 \\
\hline 弱 & 3.87 & 强 & 5.12 & 弱 & 3.85 & & & & \\
\hline 弱 & 3.35 & 中 强 & 4.83 & 弱 & 3.29 & & & & \\
\hline & & & & 總 & 括 & & & & \\
\hline
\end{tabular}

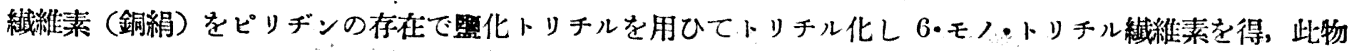
を更にピリヂンの存在で無水醋酸を用ひて醋酸化して 2,3-Diacetyl-6-mono-trityl cellulose を得, 是をク口 ロフォルムに溶解し乾燥 $\mathrm{HCl}$ を使用せしめてトリチル基を除き 2,3-Diacetyl cellulose を得た。

此物賀は從來知られて居る醋酸緎維素と明かに巽る $X$ 線圆を與へる。

トリチル基が第 1 級の $-\mathrm{OH}$ のみに結合する事に着目し，市販のアセトン可溶性の醋酸瀻維素をトリチル化 したのに，遊離の $-\mathrm{OH}$ の約 $1 / 3$ がトリチル化された。其故に全體の遊㒕の $-\mathrm{OH}$ の $1 / 3$ は 6 の第 1 級の

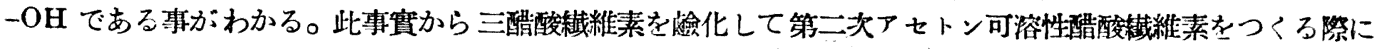
何等選擇的の龉化の起らない事が推定出來る。

（大阪帝四大學工學部應用化學科研究空）（昭和 9 年 7 月 23 日受理）

\section{石岩灰の 耐火度に關する 研究 (第 3 報) 酸化性氣中に於ける本邦産石炭灰耐火度測定結果に就て}

香坂要三郎・戶田八郎・北川長次郎

石炭の燃燒又は瓦斯化作業等に於けるクリンカー生成の可能性並に除灰作業の蜼易は蠦作業溫度及爐內雾圍 氣等と關聯して灰の耐火度郎ち (1) 灰の軟化粘着性を呈する溫度, (2) 軟化崩壊する溫度, (3) 流動化溫度並 にその流動度，(4) 生成クリンカーの機諓的性狀等に左右さるべきは明かなり。著者等は本研究第 1 報及第 2 報（本訫，昭和 9，37，206，425）に於て灰耐火度測定法としてその考案による塔敂曲線法を旺示し，且これに 依て灰の上記諸性狀を明確に表示し得べき事を報告せり。本報に於ては同法を以て求めたる本邦座各種石炭灰 に對する酸化性氣中の耐火度實測結果に就き述べんとするものなり。

\section{I. 石炭試料並飞灰試料}

試料石炭は本邦主要炭鍰及滿洲座炭等廣くこれを求めたり。これ等圾料の工業分析結果を示せば第 1 表の如

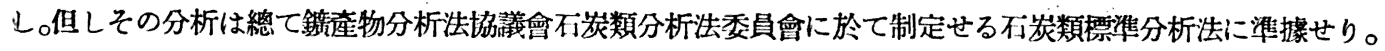

第 1 表 試料不炭工業分析表

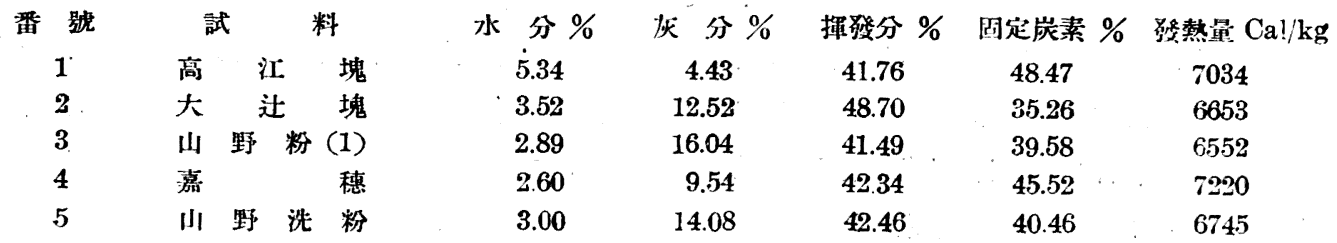

